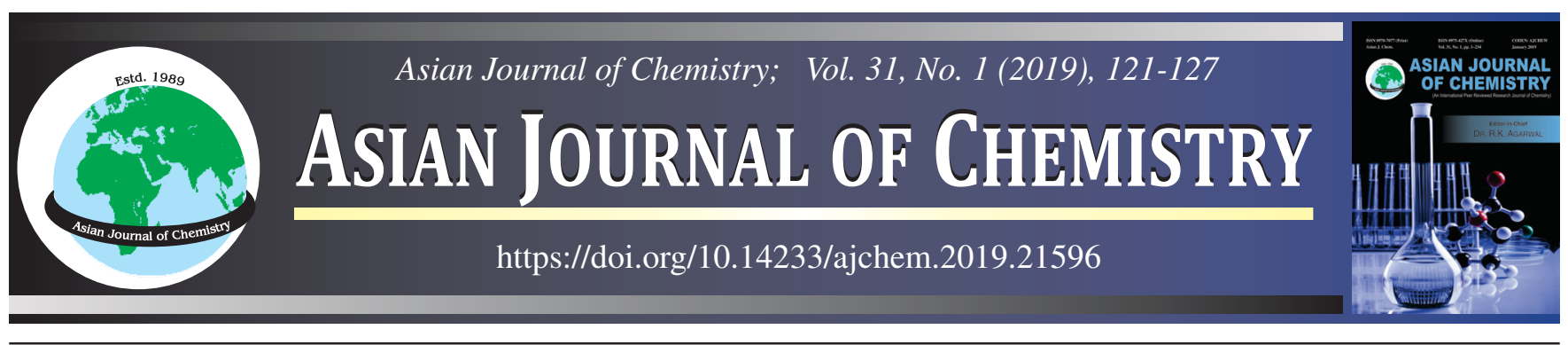

\title{
Preparation and Applications of Modified Chitosan based Carbobetaine Gel System for Treatment of Acephate Contaminated Water
}

\author{
NAZia Tarannum**, Rizwan Khan and Prashant Singh
}

Department of Chemistry, Chaudhary Charan Singh Meerut University, Meerut-250005, India

*Corresponding author: E-mail: naz1012@gmail.com

Received: 19 July 2018; Accepted: 30 August 2018;

Published online: 30 November 2018;

The pesticide toxicity and its degradation product may lead to the need of devising techniques for treatment of pesticide contaminated water. In present study, we have attempted to manage chitin waste to chitosan based gel system, which was put to an ecofriendly application of removal of acephate, a representative of organophosphate pesticide, from contaminated water. The isolated chitosan from chitin biowaste was characterized for solubility, viscosity, particle size, degree of deacetylation and molecular weight determination. Further, chitosan I was treated with glutaraldehyde and nitrogen centers of this extended chain were quaternized with $\gamma$-butyrolactone to form carbobetaine gel system. An external crosslinker is also used for better gelation property. The prepared chitosan based carbobetaine gel system was used to treat acephate contaminated water. The work aims to manage chitin biowaste to chitosan as a precursor to generate value added product from low cost materials to solve environmental issues.

Keywords: Chitin, Chitosan, Acephate, Organophosphate pesticide, Carbobetaine, Gel system, Water treatment.

\section{INTRODUCTION}

The contamination of surface and ground water by pesticides has become a serious environmental issue in recent years due to the extensive application of agrochemicals in crop farms, orchards, fields and forest lands. Various sources like leaching, surface runoff, industrial discharge and wind erosion are responsible for such contamination [1-3]. Pesticides are harmful to life because of their toxicity, carcinogenicity and mutagenicity [4]. The toxic effect of pesticides on health and environment has resulted in formulating severe legislation on quality of drinking water in most of the countries [5]. Acephate is an organophosphate foliar insecticide, used mainly in vegetables and horticulture for controlling aphids and other resistant species. It also controls leaf miners, cater-pillars, sawflies and thrips in crops and forestry. The half-life $\left(T_{1 / 2}\right)$ of acephate varies from 3 to 6 days. The toxic degradation products of pesticides have imposed serious hazard to environment [6]. In present work, acephate is used as the representative of organophosphate. Acephate is the pesticide commonly available in the local market of Meerut, Uttar Pradesh, India. Since this zone of India (western Uttar Pradesh) is well known for farming of sugarcane and other seasonal vegetables. The pesticide, which is used frequently in this zone is acephate, which caused heavy water contamination. Hence, there is a need for cost effective and robust means of water treatment. Several methods commonly known for removal of pesticides from water includes photo catalytic degradation $[7,8]$, photo-Fenton treatment with ultrasound [9], advanced oxidation processes [10], aerobic degradation [11], electro dialysis membranes [12], ozonation [13] and adsorption [14].

The adsorption process is amongst the most efficient, economic and friendly method of removing pollutants from wastewater. Moreover, the adsorption process is effectively significant if the adsorbent is cheap and available readily [15]. Researchers have explored the possibility of different inexpensive adsorbents like peat, silica, activated carbon, chitin, fly ash, clay and others [16-25]. Chitosan (nitrogenous polysaccharide) is a biomaterial obtained economically and in large quantities from chitin, a carbohydrate based biopolymer. The sources of chitin are crustaceans skeleton like crab, lobster and shrimp and also the exoskeleton of marine zooplanktons [26]. The wings of butterflies and ladybug and the cell walls of yeast and other fungi have chitin as the source material [27].

This is an open access journal, and articles are distributed under the terms of the Creative Commons Attribution-NonCommercial 4.0 International (CC BY-NC 4.0) License, which allows others to copy and redistribute the material in any medium or format, remix, transform, and build upon the material, as long as appropriate credit is given and the new creations are licensed under the identical terms. 
Chitin is a linear biopolymer of monomer unit, acetylamino D-glucose. The deacetylation of chitin with acetamide group at C-2 position forms chitosan. Chitosan with high availability of amino and hydroxyl groups show application as an adsorbent for dyes, metal ions and proteins [18,28,29]. The features that make chitosan a potential candidate for value added products include its biocompatibility, antibacterial property, hydrophilicity and biodegradability [30]. Chitosan possess good adsorption capability because of low porosity and weak mechanical property. Other widespread application of chitosan and its derivatives include biomedicine, food preservation, pharmacy [31-38], cosmetics [30], biotechnology [39], dietary supplements, water treatment and agriculture [40]. However, few studies have reported the utilization of chitosan in water treatment and pesticides removal. Chitosan, a lowcost material derived from chitin waste, may be used as a precursor to provide resolution to serious environmental threats imposed by pesticides in water.

In this study, we have made an attempt to synthesize chitosan from biowaste (chitin obtained from shrimp shell) by their deproteination and deacetylation at ambient temperature and pressure condition. Further, the gel forming property and biodegradability of chitosan was explored and it was used to prepare gel system with better adsorption capacity. The chitosan based gel system was used for the removal of acephate from contaminated water.

\section{EXPERIMENTAL}

The following chemicals have been procured: potassium hydroxide (Qualigens), sodium hydroxide (Fisher Scientific), oxalic acid (Qualigens), $\gamma$-butyrolactone (Loba Chemie), methanol (Qualigens), acetone (Fisher scientific), potassium permanganate (Qualigens), hydrochloric acid (Qualigens), $\mathrm{N}, \mathrm{N}$-methylene-bis-acrylamide (MBA) (Sisco Research lab. India) and glutaraldehyde (25\%) (Central Drug House). The organophosphate pesticide used was acephate $(75 \%)$ procured from TATA ASATAF manufactured by Rallis India Limited (Mumbai Maharashtra).

UV-visible spectroscopy was carried out by systronic T2201 double beam spectrophotometer. FTIR spectra of compounds were recorded on cary 630 FTIR, Agilent Technologies. Differential scanning calorimetry (DSC) was recorded on DSC7020 thermal analysis system Hitachi. TGA/DTA thermogravimetric analysis was carried out by Perkin Elmer, Diamond TG/DTA. Elemental analysis was performed by Elementar Vario EL III. Scanning electron microscopy (SEM) was carried out on Evo18 SEM from Carl Zeiss, Germany. Gravimetric analysis was done using Excel electronic scale (0.001-300 g).

Pretreatment of chitin waste: Chitin waste was collected in the form of post consumed shrimp shells from sea food shops in New Delhi, India. They were washed thoroughly with water to remove adherent proteins, organics and impurities and dried at $70{ }^{\circ} \mathrm{C}(24 \mathrm{~h})$ in oven. Further, the decalcification of chitin material was carried out at room temperature using $1 \mathrm{M}$ hydrochloric acid $(3.0 \% \mathrm{w} / \mathrm{v})$ with regular stirring for $1.5 \mathrm{~h}$. Thereafter, the product was filtered, washed and dried and deproteinized at $50{ }^{\circ} \mathrm{C}$ using $4 \%$ solution of sodium hydroxide with constant stirring of $5 \mathrm{~h}$. The treated deproteinized material was washed with deionized water until neutral $\mathrm{pH}$ is attained. The material was dehydrated with methanol and acetone and dried well. The chitinous material was boiled with $0.1 \%$ potassium permanganate and $15 \%$ oxalic acid solution to remove the odor and colour. The pretreated chitin was filtered, washed with distilled water and dried [41].

Preparation of chitosan from chitin: The dried $200 \mathrm{~g}$ chitin was treated with $40 \%$ (w/v) solution of sodium hydroxide in three necked flask and refluxed under nitrogen atmosphere at $135-140{ }^{\circ} \mathrm{C}$ for $2 \mathrm{~h}$ to prepare chitosan [42]. The deacetylated chitin (chitosan) was filtered, washed with distilled water and dried. Then the material was grounded using ball mill. The yield $68 \%$ of chitosan was obtained.

Preparation of chitosan based gel system: The deacetylated chitin waste was used to prepare chitosan based gel system; one without external crosslinker MBA, which was abbreviated G-1 and other with external crosslinker MBA, which was abbreviated G-2. Chitosan [2 \% (w/v)] was dissolved in $1 \%(\mathrm{v} / \mathrm{v})$ aqueous acetic acid at room temperature to form G-1. This viscous solution was filtered to remove any impurities and treated with $15 \mathrm{~mL}$ glutaraldehyde $(25 \%)$ at room temperature with constant stirring for $24 \mathrm{~h}$. A sticky solution was obtained, which was reacted with $0.18 \mathrm{~mL}$ $\gamma$-butyrolactone and left undisturbed for 4 days.

Gel system G-2 was prepared by dissolving $2 \%(\mathrm{w} / \mathrm{v})$ chitosan in $1 \%(\mathrm{v} / \mathrm{v})$ aqueous acetic acid with constant stirring at room temperature. The viscous solution prepared was filtered through a cheese cloth to remove any impurities. Then solution was treated with $15 \mathrm{~mL}$ glutaraldehyde $(25 \%)$ with constant stirring for $24 \mathrm{~h}$ at room temperature. A sticky solution was obtained, which was reacted with $0.18 \mathrm{~mL} \gamma$-butyrolactone and refluxed for $1 \mathrm{~h}$, then added $0.25 \mathrm{~g}$ MBA and left the solution for 4 days undisturbed.

Sorption capacity of chitosan: The known weight of chitosan, G-1 and G-2 were added to the pesticide solution (acephate) kept in a sealed beaker at room temperature until equilibrium was reached. Polymer (Chitosan, G-1 and G-2) were removed and blotted dry. The swelling ratio of the polymer was determined gravimetrically. All the analysis were recorded in triplicate. The swelling ratio \% of the polymer gels were calculated from the ratio of the weight of the equilibrated polymer to the dry weight as give below:

$$
\text { Swelling ratio }(\%)=\frac{\mathrm{W}_{\mathrm{S}}-\mathrm{W}_{\mathrm{d}}}{\mathrm{W}_{\mathrm{d}}} \times 100
$$

where $\mathrm{W}_{\mathrm{S}}$ = weight of swollen gel; $\mathrm{W}_{\mathrm{d}}=$ weight of dry gel.

\section{RESULTS AND DISCUSSION}

The copolymer of chitosan and glutaraldehyde was synthesized based on Schiff base chemistry. Polyimines, nitrogenous analogs of carbonyl functional group also known as poly-Schiff bases were synthesized here. The functional groups aldehydes and ketones when reacted with primary amines and other ammonia derivatives form imines, via nucleophilic additionelimination reaction [43]. In this mechanism of Schiff base generation, the non bonded electrons on nitrogen cause water to be eliminated and further subsequent loss of a proton from the resulting protonated imine forms a stable imine. Chitosan 
contains one amino and two hydroxyl groups, which are capable of reacting with nucleophiles. The most favourable nucleophilic centre of chitosan are its amino groups while the other one hydroxyl groups are less reactive [44]. The nitrogen centre in the chitosan glutaraldehyde copolymer was quaternized by $\gamma$-butyrolactone form carbobetaine. Fig. 1 shows the schematic route of synthesis of copolymer of chitosan and glutaraldehyde and its betainization to form polycarbobetaine. Solution of betainized chitosan was treated with MBA as an external crosslinker. The extent of gelation as well as time period needed for gelation depends on the amount of crosslinker added. Crosslinking of polymeric chains either inter-chain or intrachain arise from Michael type addition of acryl amide groups with free $\mathrm{NH}_{2} / \mathrm{OH}$ group.
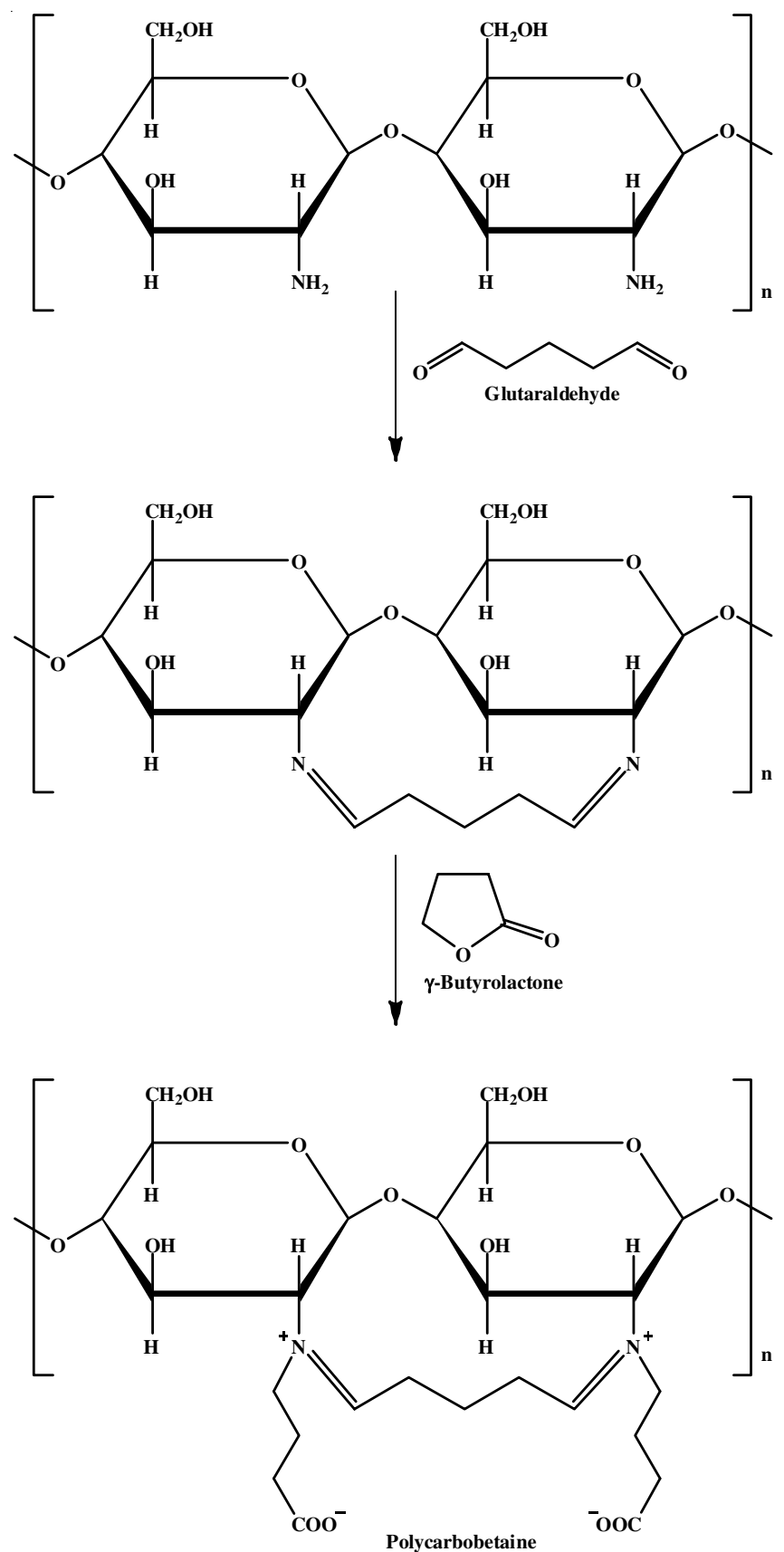

Fig. 1. Synthetic route for copolymer of chitosan and glutaraldehyde and its betainization to form polycarbobetaine
Characterization: The isolated chitosan from biowaste was white flake like without any characteristics odor and taste. The chitosan was characterized for solubility, viscosity and particle size, degree of deacetylation and molecular weight determination. It was sparingly soluble in water, poorly soluble in $0.1 \mathrm{~N}$ hydrochloric acid practically insoluble in ethanol, other organic solvents and neutral or alkali solutions. Chitosan dissolved readily in dilute and concentrated solution of most organic acids. Particle size of powdered chitosan was determined by sieve analysis. Sieves 20-100 were used and checked properly for their integrity. The particle size of chitosan was found to be approximately $170 \mu \mathrm{m}$.

The viscosity of the prepared chitosan was determined by using an Ostwald viscometer at $25^{\circ} \mathrm{C}$ in $0.3 \mathrm{M}$ acetic acid. The intrinsic viscosity [ $\eta$ ] of the prepared chitosan was 26.91 $\mathrm{mL} / \mathrm{g}$. The relation used for calculation of $[\eta]$ is given below.

$$
\eta_{\mathrm{L}}=\frac{\eta_{\mathrm{W}} \times \rho_{\mathrm{L}} \mathrm{t}_{\mathrm{L}}}{\rho_{\mathrm{W}} \times \mathrm{t}_{\mathrm{W}}}
$$

where $\eta_{\mathrm{W}}=$ absolute viscosity of water; $\eta_{\mathrm{L}}=$ absolute viscosity of chitosan solution; $\rho_{\mathrm{L}}=$ density of chitosan solution; $\rho_{\mathrm{W}}=$ density of water; $t_{W}=$ time of flow of water; $t_{L}=$ time of flow of chitosan solution.

The deacetylated chitin (chitosan) was subjected to infrared spectroscopy to calculate the degree of deacetylation (DDA) \%, by following relationship. Fig. 2(b) shows the FTIR spectrum of chitosan.

$$
\operatorname{DDA}(\%)=1-\left(\frac{\mathrm{A}_{1655} / \mathrm{A}_{3450}}{100 \times 1.33}\right)
$$

where, 1.33 = ratio of $\mathrm{A}_{1655} / \mathrm{A}_{3450}$ for fully $N$-acetylated chitosan; $\mathrm{A}_{1655}=$ absorbance of amide-1 $(\mathrm{NH})$ at $1655 \mathrm{~cm}^{-1} ; \mathrm{A}_{3450}=$ absorbance of $\mathrm{OH}$ group at $3450 \mathrm{~cm}^{-1}$. Degree of deacetylation (\%) of chitosan thus calculated was about $98.77 \%$. As per the literature survey, higher \% of DDA reflects the quality of chitosan prepared. The formation of chitosan from chitin is confirmed when the DDA (\%) is above 60 .

Molecular weight determination was done based upon viscosity technique. The viscosity-average molecular weight was calculated using Mark-Houwink equation relating to intrinsic viscosity.

$$
[\eta]=\mathrm{K}_{\mathrm{m}} \mathrm{M}_{\mathrm{v}^{\mathrm{a}}}
$$

where $\mathrm{K}_{\mathrm{m}}=2.4 \times 10^{-3}$ and $\mathrm{a}=0.69$ at $25^{\circ} \mathrm{C}$ are the empirical viscometer constants that are specific for a given polymer, solvent and temperature. The viscosity-average molecular weight $\left(\mathrm{M}_{\mathrm{V}}\right)$ for the chitosan prepared was $7.4 \times 10^{5} \mathrm{~g} / \mathrm{mL}$.

FTIR analysis: FTIR spectrum of chitin shows a single band at $3422.79 \mathrm{~cm}^{-1}$ assigned to $\mathrm{OH}$ group stretching and a band at $1310.96 \mathrm{~cm}^{-1}$ was assigned to $\mathrm{CN}$ group stretching. A characteristic band at $1028.85 \mathrm{~cm}^{-1}$ was due to C-O group stretching. The band due to NH stretching was observed at 3331.03 $\mathrm{cm}^{-1}$ and $3255.90 \mathrm{~cm}^{-1}$. A strong band at $1601.27 \mathrm{~cm}^{-1}$ in the spectrum was assigned to the presence of $\mathrm{C}=\mathrm{O}$ group. Fig. 2 shows the FTIR spectrum of chitin (A), chitosan (B), chitosan based gel system without crosslinker (G-1) (C) and with crosslinker (G-2) (D). The band at $3642.371 \mathrm{~cm}^{-1}$ was due to $\mathrm{NH}$ stretch confirming the formation of chitosan. A single band observed in spectrum at $3422.79 \mathrm{~cm}^{-1}$ was due to $\mathrm{OH}$ group. 
Moderate peaks at $3242.371 \mathrm{~cm}^{-1}, 3108.090 \mathrm{~cm}^{-1}$ and 2878.026 $\mathrm{cm}^{-1}$ referred to C-H group stretching. The band due to NH stretching at $1624.12 \mathrm{~cm}^{-1}$ and $1551.42 \mathrm{~cm}^{-1}$ can be seen clearly in the spectrum. C-C stretching at $1419.22 \mathrm{~cm}^{-1}$ and C-O stretching at $1376.40 \mathrm{~cm}^{-1}$ and $1316.73 \mathrm{~cm}^{-1}$ can be observed in the spectrum.

FTIR spectrum of G-1 shows a single band at 3368.80 $\mathrm{cm}^{-1}$ assigned to the stretching of the $\mathrm{OH}$ group. Moderate peaks at $2937.99 \mathrm{~cm}^{-1}$ and $2869.60 \mathrm{~cm}^{-1}$ were referred to the stretching of $\mathrm{C}-\mathrm{H}$ group. The band due to asymmetric stretching of carboxylate at $1717.39 \mathrm{~cm}^{-1}$ can be seen clearly in the spectrum. The characteristic absorption at $1606 \mathrm{~cm}^{-1}$ was referred to $\mathrm{C}=\mathrm{N}$ group. $\mathrm{C}-\mathrm{C}$ ring stretching was observed at $1406.43 \mathrm{~cm}^{-1}$ and $\mathrm{C}-\mathrm{O}$ stretching at $1009.86 \mathrm{~cm}^{-1}$ and 949.02 $\mathrm{cm}^{-1}$. The primary $\mathrm{N}-\mathrm{H}$ stretch is absent here since the $\mathrm{NH}_{2}$ group is condensed with aldehyde to give $\mathrm{C}=\mathrm{N}$.

FTIR spectrum of G-2 shows band at $3500-3300 \mathrm{~cm}^{-1}$ contributing to the $\mathrm{NH}_{2}$ stretching of the primary amine and the band at $3500-3200 \mathrm{~cm}^{-1}$ corresponds to $\mathrm{OH}$ bonded groups. A single band observed in spectrum at $3377.80 \mathrm{~cm}^{-1}$ was commonly assigned to the stretching of the $\mathrm{OH}$ group. Moderate peaks at $2940.11 \mathrm{~cm}^{-1}$ and $2870.23 \mathrm{~cm}^{-1}$ referred to the stretching of $\mathrm{C}-\mathrm{H}$ group. The band due to asymmetric stretching of carboxylate at $1717.83 \mathrm{~cm}^{-1}$ can be seen clearly in the spectrum. The band at $1676.37 \mathrm{~cm}^{-1}$ was referred to $\mathrm{C}=\mathrm{N}$ group. $\mathrm{C}-\mathrm{C}$ ring stretching at $1438.16 \mathrm{scm}^{-1}$ and $\mathrm{C}-\mathrm{N}$ stretch at $1354.70 \mathrm{~cm}^{-1}$ and $1110.04 \mathrm{~cm}^{-1}$. C-O stretching at $1010.10 \mathrm{~cm}^{-1}$ and 945.68 $\mathrm{cm}^{-1}$ can be observed in the spectrum.

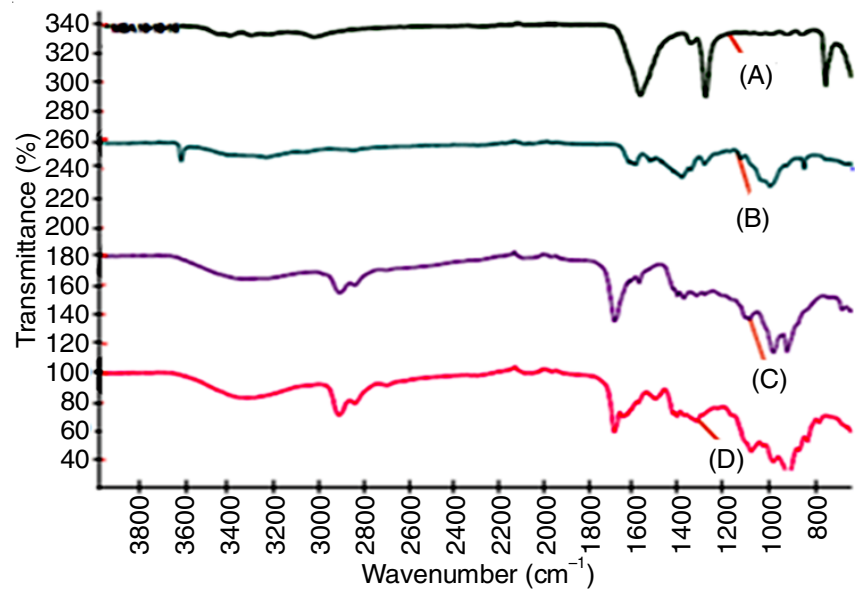

Fig. 2. FTIR spectrum of chitin (A), chitosan (B), G-1 (C), G-2 (D)

Thermal analysis: Thermogravimetric and differential thermal analysis (TGA/DTA) and differential scanning calorimetry (DSC) was performed for chitosan to study their physical behaviour with respect to temperature. TGA/DTA was performed using a $10 \mathrm{mg}$ sample from ambient temperature up to $720{ }^{\circ} \mathrm{C}$ at heating rate of $20^{\circ} \mathrm{C} / \mathrm{min}$ in nitrogen atmosphere. TGA thermogram of chitosan has no loss in the weight of the compounds up to $100{ }^{\circ} \mathrm{C}$ temperature. The maximum weight loss was observed in between $328-480^{\circ} \mathrm{C}$ temperature range. Chitosan remains thermally stable upto $620^{\circ} \mathrm{C}$. Fig. 3a, shows TGA curve of chitosan.

DSC thermogram shows that weight loss occurs in two stages. The first starts at $126.3^{\circ} \mathrm{C}$ and second at $238.4^{\circ} \mathrm{C}$. The first stage was assigned to loss of water because polysaccharides usually have a strong affinity for water and therefore may be easily hydrated. The second one corresponds to the thermal decomposition. The decomposition temperature of chitosan was found to be $238.4{ }^{\circ} \mathrm{C}$. This indicates that chitosan exist as a stable structure towards thermal decomposition. The optimum temperature to melt the chitosan sample was found to be $126.39{ }^{\circ} \mathrm{C}$ at $-3.94(\mathrm{~mJ} / \mathrm{mg})$. Fig. 3b shows DSC thermogram of synthesized chitosan.
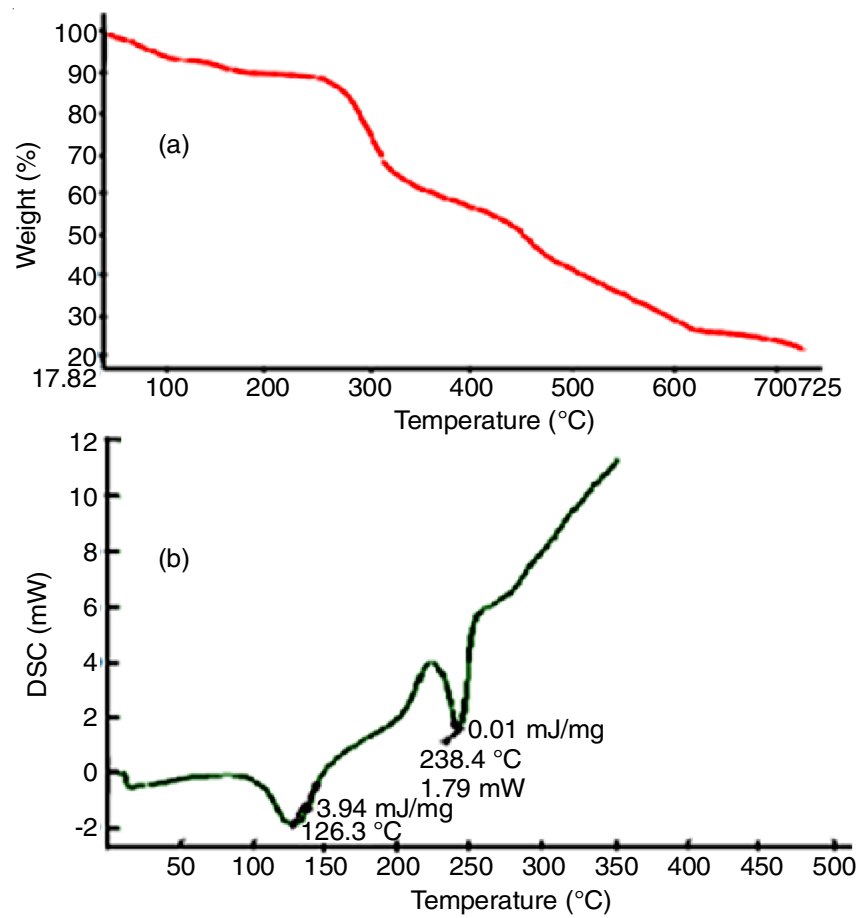

Fig. 3. (a) TGA/DTA and (b) DSC thermogram of the prepared chitosan

Scanning electron microscopy (SEM): Fig. 4 represents SEM image of sorbent (Gel-2) before (a) and after (b) sorption of acephate. The micrographs after sorption of organophosphate show irregular adhered surface due to adsorbate molecules; the morphology before adsorption show plain surface.

Modified chitosan as biosorbent: Fig. 5 suggests that chitosan showed less $\%$ of swelling and deswelling whereas G-1 and G-2 comparatively showed good sorption capacity. The $\%$ of pesticide adsorbed by G- 1 is higher about $312.72 \%$ than G-2 about $282.82 \%$. G-2 is a polymer with crosslinker, which keeps the polymer intact and stable enough to be handled whereas in case of G-1 without crosslinker, the polymer started losing its gel like characteristic in pesticide solution at equilibrium. The modified chitosan was explored for its swelling and deswelling property. $0.1 \mathrm{~g}$ of chitosan showed $47.23 \%$ of sorption capacity. The known weight of dried samples of G-1 and G-2 were kept in acephate solution till swelling equilibrium has reached $(2 \mathrm{~h})$ and the weight of the gel systems were observed each after $20 \mathrm{~min}$. The same experiment was repeated with chitosan sample as well. The chitosan material showed poor adsorption property as compared to modified chitosan material. Further, chitosan was difficult to handle after prolonged swelling. Hence, G-2 was a better sorbent then G-1. The gel systems G-1 and G-2 were recycled thrice i.e. they were reused after deswelling, although the $\%$ of swelling decreased in second 

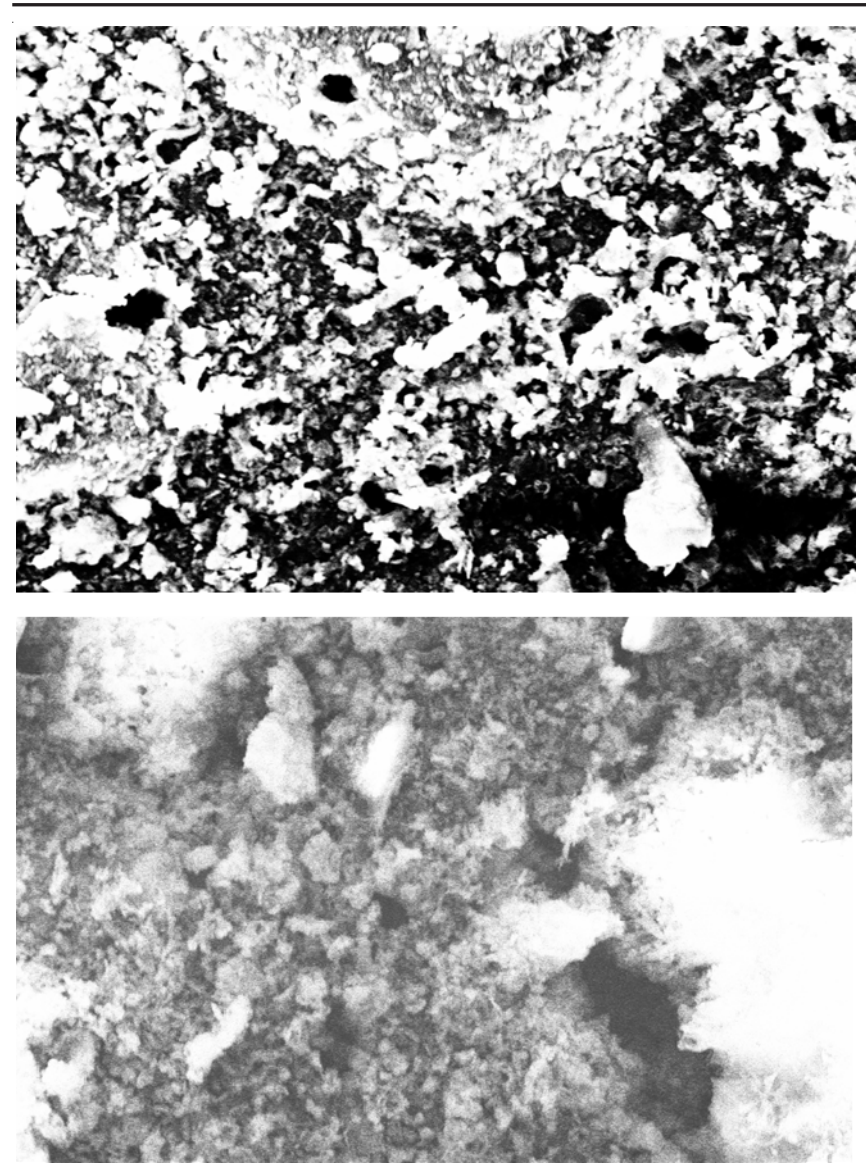

Fig. 4. SEM micrograph of Gel-2 (a) before sorption, (b) after sorption of acephate

and third attempt. The modified chitosan gel system with excellent swelling and deswelling property can be used as a
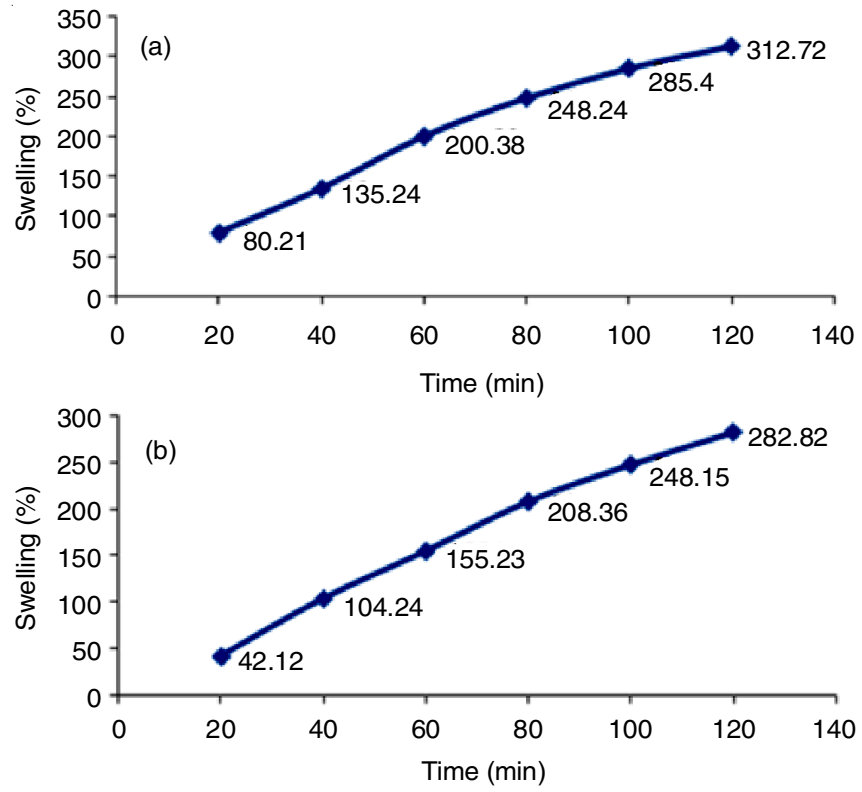

Fig. 5. Swelling \% with respect to time (a) G-1, (b) G-2

cost effective, biosorbent for treating water contaminated with pesticide. In order to minimize the potential secondary pollution, the material has been reused thrice. The material was recycled after desorption.

Table-1 shows a close comparison of chitosan based carbobetaine gel system with that of other modified chitosan material reported so far, used in waste water treatment and their efficiency. The high quality modified chitosan material reported herein is developed from shrimp waste and can be reused avoiding secondary pollution to an extent. The \% of adsorption and desorption is also good as compared to other materials.

TABLE-1

COMPARATIVE REPRESENTATION OF REPORTED MODIFIED CHITOSAN MATERIALS AND THEIR APPLICATION AND EFFICIENCY

\begin{tabular}{|c|c|c|c|c|}
\hline $\begin{array}{l}\text { S. } \\
\text { No. }\end{array}$ & Modified chitosan material & Application & Efficiency & Ref. \\
\hline 1 & $\begin{array}{l}\text { Shrimp chitosan based } \\
\text { carbobetaine gel system }\end{array}$ & $\begin{array}{l}\text { Removal of acephate from } \\
\text { water }\end{array}$ & $\begin{array}{l}\text { Maximum adsorption } \% \text { by modified gel system was } 282 \% \\
\text { whereas chitosan showed adsorption of } 47 \% \text {. Can be reused } \\
\text { upto } 3 \text { times }\end{array}$ & $\begin{array}{c}\text { Present } \\
\text { study }\end{array}$ \\
\hline 2 & $\begin{array}{l}\text { Composite chitosan- } \\
\text { based hydrogels containing } \\
\text { hyper-crosslinked polymer }\end{array}$ & $\begin{array}{l}\text { Removal of dyes from } \\
\text { aqueous solutions }\end{array}$ & $\begin{array}{l}\text { Both anionic and cationic dyes from water are removed by } \\
\text { adsorption experiments through synergistic effect. The dye } \\
\text { uptake is higher than that of comparable biosorbent. Further, } \\
\text { the mechanical propertyof composite hydrogels are much } \\
\text { better than pure CS and the material is recycled with } \\
\text { maximum adsorption efficiency over successive cycles of } \\
\text { adsorption, desorption and washing. }\end{array}$ & [45] \\
\hline 3 & Shrimp chitosan & $\begin{array}{l}\text { Removal of dye from waste } \\
\text { water }\end{array}$ & $\begin{array}{l}\text { Maximum removal of dye (about } 100 \%) \text { was obtained by } \\
\text { passing } 100 \mathrm{~mL} \text { of DB- } 86\left(50 \mathrm{mg} \mathrm{L} \mathrm{L}^{-1}, \mathrm{pH}=2\right) \text { through a } \\
\text { column containing } 0.5 \mathrm{~g} \text { chitosan. Maximum desorption of } \\
72 \% \text { was achieved at alkaline medium }(\mathrm{pH}=13.5) \text {. }\end{array}$ & [46] \\
\hline 4 & $\begin{array}{l}\text { Chitosan-based adsorbents } \\
\text { gels }\end{array}$ & $\begin{array}{l}\text { Removal of Tris-azo dye from } \\
\text { aqueous solutions }\end{array}$ & $\begin{array}{l}\text { Maximum adsorption capacity of the adsorbent for dye was } \\
88.49 \mathrm{mg} / \mathrm{g} \text { (linear form) and } 92.22 \mathrm{mg} / \mathrm{g} \text { (non-linear form). }\end{array}$ & [47] \\
\hline 5 & Chitosan & $\begin{array}{l}\text { Removal of ethoprophos } \\
\text { pesticide from aqueous } \\
\text { solution }\end{array}$ & $\begin{array}{l}\text { The removal percentage of ethoprophos increased from } \\
85.693 \% \text { to } 89.234 \% \text {, as adsorbent dose }(\mathrm{CH}) \text { increased } \\
\text { from } 0.02 \text { to } 0.1 \mathrm{~g} / 100 \mathrm{~mL} \text {. }\end{array}$ & [41] \\
\hline 6 & $\begin{array}{l}\text { Chitosan- } \mathrm{ZnO} \text { nanoparticles } \\
\text { composite beads }\end{array}$ & $\begin{array}{l}\text { Removal of permethrin } \\
\text { pesticide from water }\end{array}$ & $\begin{array}{l}\text { The removal efficiency of CS/ZnONPs beads increased } \\
\text { from } 49 \% \text { to } 99 \% \text { for } 25 \mathrm{~mL} \text { of Permethrin solution }(0.1 \\
\left.\mathrm{mg} \mathrm{L}^{-1}\right) \text {. The adsorption and regeneration studies of } \\
\text { permethrin demonstrated that the CS/ZnONPs beads could } \\
\text { be reused effectively with } 56 \% \text { regeneration after } 3 \text { cycles } \\
\text { in on-line column. }\end{array}$ & [48] \\
\hline
\end{tabular}




\begin{tabular}{|c|c|c|c|c|}
\hline 7 & Nanochitosan and chitosan & $\begin{array}{l}\text { Comparative cadmium } \\
\text { adsorption from water }\end{array}$ & $\begin{array}{l}\text { The maximum adsorption capacities for chitosan and } \\
\text { nanochitosan adsorbents were } 153 \text { and } 358 \mathrm{mg} / \mathrm{g} \\
\text { respectively. }\end{array}$ & [49] \\
\hline 8 & $\begin{array}{l}\text { Chitosan coated calcium } \\
\text { alginate }\end{array}$ & $\begin{array}{l}\text { Removal of } \mathrm{Ni}(\mathrm{II}) \text { from } \\
\text { aqueous solutions }\end{array}$ & $\begin{array}{l}\text { The maximum adsorption capacity for chitosan coated } \\
\text { calcium alignate was } 222.2 \mathrm{mg} / \mathrm{g} \text {. Ni(II) loaded material was } \\
\text { regenerated using } 0.1 \mathrm{M} \text { EDTA solution. }\end{array}$ & [50] \\
\hline 9 & Chitosan coated silica & $\begin{array}{l}\text { Removal of } \mathrm{Ni}(\mathrm{II}) \text { from } \\
\text { aqueous solutions }\end{array}$ & $\begin{array}{l}\text { The maximum adsorption capacity for chitosan coated silica } \\
\text { was } 254.2 \mathrm{mg} / \mathrm{g} \text {. The Ni(II) loaded material was regenerated } \\
\text { using } 0.1 \mathrm{M} \text { EDTA solution. }\end{array}$ & [50] \\
\hline
\end{tabular}

\section{Conclusion}

In conclusion, a potentially applicable compound chitosan was prepared from the biowaste (chitin) by their deproteination and deacetylation at ambient temperature and pressure conditions. Chitin contains acetyl group, which makes it difficult to dissolve in any organic and inorganic solvent resulting in its limited application. To resolve this problem, chitin was deacetylated to form a biopolymer chitosan. Degree of deacetylation of prepared chitosan calculated from FTIR absorption spectrum was about $98.77 \%$. As per the literature survey, higher DDA \% reflects the quality of chitosan prepared. Chitosan bearing amide group possess different interesting properties like gel and film forming ability, biodegradability, bioadhesion, biocompatibility and swelling property. Since swelling property of chitosan was not good, so there was a need to modify it synthetically to swelling nature by preparing chitosan based gel system. We have attempted to prepare modified chitosan with glutaraldehyde and $\gamma$-butyrolactone. The copolymer is formed by condensation of amide of chitosan and aldehyde group of glutaraldehyde, which on further treatment with lactone forms carbobetaine. Further, the two betainized gel systems; one with crosslinker and other without crosslinker were prepared and studied for their sorption capacity. The chitosan based gel system showed good swelling and deswelling property and hence have been employed to treat pesticide contaminated water. The synthesized gel system can be recycled after use and was found to be an economic and effective measure for wastewater treatment.

\section{ACKNOWLEDGEMENTS}

The authors acknowledge to SAIF, Cochin, India for carrying out TGA/DTA, elemental and SEM analyses. Financial support from University Grant Commisson, New Delhi, India is also acknowledged.

\section{CONFLICT OF INTEREST}

The authors declare that there is no conflict of interests regarding the publication of this article.

\section{REFERENCES}

1. Environment Agency, The Annual Report of the Environment Agency Pesticide Monitoring Programme, Environment Agency (2002).

2. G. Akcay, M. Akcay and K. Yurdakoc, J. Colloid Interface Sci., 281, 27 (2005);

https://doi.org/10.1016/j.jcis.2004.08.080.

3. R.A. Rebich, R.H. Coupe and E.M. Thurman, Sci. Total Environ., 321, 189 (2004);

https://doi.org/10.1016/j.scitotenv.2003.09.006
4. WHO, Lyon International Agency for Research on Cancer (IARC), Overall Evaluations of Carcinogenicity: An Updating of IARC Monographs, vols. 1-42, No. S7 (1987).

5. A. Derylo-Marczewska, M. Blachnio, A.W. Marczewski, A. Swiatkowski and B. Tarasiuk, J. Therm. Anal. Calorim., 101, 785 (2010); https://doi.org/10.1007/s10973-010-0840-7.

6. H.H. Philip, E.M. Michalenko, W.F. Jarvis, G.W. Sage, W.M. Meyland, J.A. Beauman and D.A. Gray, Handbook of Environmental Fate and Exposure Data for Organic Chemicals, Lewis: Chelsea. vol. III (1991).

7. M. Ugurlu and M.H. Karaoglu, Chem. Eng. J., 166, 859 (2011); https://doi.org/10.1016/i.cej.2010.11.056.

8. J. Gong, C. Yang, W. Pu and J. Zhang, Chem. Eng. J., 167, 190 (2011); https://doi.org/10.1016/j.cej.2010.12.020.

9. H. Katsumata, T. Kobayashi, S. Kaneco, T. Suzuki and K. Ohta, Chem. Eng. J., 166, 468 (2011); https://doi.org/10.1016/j.cej.2010.10.073

10. T. Zhou, T.T. Lim, S.S. Chin and A.G. Fane, Chem. Eng. J., 166, 932 (2011); https://doi.org/10.1016/j.cej.2010.11.078.

11. H.M.R. Murthy and H.K. Manonmani, J. Hazard. Mater., 149, 18 (2007); https://doi.org/10.1016/j.jhazmat.2007.03.053.

12. L.J. Banasiak, B. Van der Bruggen and A.I. Schäfer, Chem. Eng. J., 166, 233 (2011); https://doi.org/10.1016/j.cej.2010.10.066.

13. M.I. Maldonado, S. Malato, L.A. Perez-Estrada, W. Gern-jak, I. Oller, X. Domenech and J. Peral, J. Hazard. Mater., 138, 363 (2006); https://doi.org/10.1016/j.jhazmat.2006.05.058.

14. A.H. Al-Muhtaseb, K.A. Ibrahim, A.B. Albadarin, O. Ali-khashman, G.M. Walker and M.N.M. Ahmad, Chem. Eng. J., 168, 691 (2011); https://doi.org/10.1016/j.cej.2011.01.057.

15. C. Namasivayam, R. Radhika and S. Suba, Coir Pith. Waste Manage, 21, 7 (2001)

16. X.Y. Yang and B. Al-Duri, Chem. Eng. J., 83, 15 (2001); https://doi.org/10.1016/S1385-8947(00)00233-3.

17. G. McKay, Chem. Eng. J., 27, 187 (1983); https://doi.org/10.1016/0300-9467(83)80075-6.

18. I. Uzun and F. Guzel, Turk. J. Chem., 24, 291 (2000).

19. S.J. Allen and G. McKay, J. Sep. Process. Technol., 8, 18 (1987).

20. G. McKay, H.S. Blair and J. Gardner, J. Colloid Interface Sci., 95, 108 (1983); https://doi.org/10.1016/0021-9797(83)90078-4.

21. G. McKay, M.S. Otterburn and A.G. Sweeney, Water Res., 15, 327 (1981); https://doi.org/10.1016/0043-1354(81)90036-1.

22. G.S. Gupta, G. Prasad and V.N. Singh, Water Res., 24, 45 (1990); https://doi.org/10.1016/0043-1354(90)90063-C.

23. V.V. Sethuraman and B.C. Raymahashay, Environ. Sci. Technol., 9, 1139 (1975); https://doi.org/10.1021/es60111a013.

24. R.W. Frei and H. Zeitlin, Anal. Chim. Acta, 32, 32 (1965); https://doi.org/10.1016/S0003-2670(00)88888-1.

25. D. Roy, P.N. Greenlaw and B.S. Shane, J. Environ. Sci. Health, 28, 37 (1993).

26. F. Shahidi and R. Abuzaytoun, Adv. Food Nutr. Res., 49, 93 (2005); https://doi.org/10.1016/S1043-4526(05)49003-8.

27. R.N. Tharanathan and F.S. Kittur, Crit. Rev. Food Sci. Nutr., 43, 61 (2003); https://doi.org/10.1080/10408690390826455.

28. I. Uzun and F. Guzel, J. Colloid Interface Sci., 274, 398 (2004); https://doi.org/10.1016/j.jcis.2004.02.022.

29. X.F. Zeng and E. Ruckenstein, J. Membr. Sci., 148, 195 (1998); https://doi.org/10.1016/S0376-7388(98)00183-5. 
30. M.N.V. Ravi Kumar, React. Funct. Polym., 46, 1 (2000); https://doi.org/10.1016/S1381-5148(00)00038-9.

31. E. Agullo, M.S. Rodriguez, V. Ramos and L. Albertengo, Macromol. Biosci., 3, 521 (2003); https://doi.org/10.1002/mabi.200300010.

32. F. Shahidi, J.K.V. Arachchi and Y.J. Jeon, Trends Food Sci. Technol., 10, 37 (1999); https://doi.org/10.1016/S0924-2244(99)00017-5.

33. M. Prabaharan and J.F. Mano, Systems Drug Deliv., 12, 41 (2004); https://doi.org/10.1080/10717540590889781.

34. M.N. Kumar, R.A. Muzzarelli, C. Muzzarelli, H. Sashiwa and A.J. Domb, Chem. Rev., 104, 6017 (2004); https://doi.org/10.1021/cr030441b.

35. S.A. Agnihotri, N.N. Mallikarjuna and T.M. Aminabhavi, J. Control. Rel., 100, 5 (2004); https://doi.org/10.1016/j.jconrel.2004.08.010.

36. S. Senel and S.J. McClure, Adv. Drug Deliv. Rev., 56, 1467 (2004); https://doi.org/10.1016/j.addr.2004.02.007.

37. J. Berger, M. Reist, J.M. Mayer, O. Felt, N.A. Peppas and R. Gurny, Eur. J. Pharm. Biopharm., 57, 19 (2004); https://doi.org/10.1016/S0939-6411(03)00161-9.

38. E. Khor and L.Y. Lim, Biomater, 24, 2339 (2003); https://doi.org/10.1016/S0142-9612(03)00026-7.

39. B. Krajewska, Enzyme Microb. Technol., 35, 126 (2004); https://doi.org/10.1016/j.enzmictec.2003.12.013.

40. S. Bautista-Banos, A.N. Hernandez-Lauzardo, M.G. Velazquez-del Valle, M. Hernandez-Lopez, E. Ait Barka, E. Bosquez-Molina and C.L. Wilson, Crop Prot., 25, 108 (2006); https://doi.org/10.1016/i.cropro.2005.03.010.
41. Z. Abdeen and S.G. Mohammad, J. Org. Polym. Mater., 40, 16 (2014); https://doi.org/10.4236/ojopm.2014.41004

42. Z. Abdeen, Ph.D. Thesis, Preparation and Applications of Some Friendly Environmental Compounds, Ain-Shams University, Cairo, Egypt (2005).

43. N. Tarannum and M. Singh, J. Appl. Polym. Sci., 118, 2821 (2010); https://doi.org/10.1002/app.32393.

44. L.K. Singh, M. Singh and M. Singh, Mater. Sci. Eng. C, 45, 383 (2014); https://doi.org/10.1016/j.msec.2014.08.073.

45. M. Salzano de Luna, R. Castaldo, R. Altobelli, L. Gioiella, G. Filippone, G. Gentile and V. Ambrogi, Carbohydr. Polym., 177, 347 (2017); https://doi.org/10.1016/j.carbpol.2017.09.006.

46. M.R. Fathi and A. Ahmadi, Int. J. Environ. Health Eng., 5, 19 (2016); https://doi.org/10.4103/2277-9183.190645.

47. R.G. Sanchez-Duarte, J. Lopez-Cervantes, D.I. Sanchez-Machado, M.A. Correa-Murrieta, J.A. Nunez-Gastelum and J.R. Rodriguez-Nunez, Environ. Eng. Manag., 15, 2469 (2016); https://doi.org/10.30638/eemj.2016.270.

48. S. Moradi Dehaghi, B. Rahmanifar, A.M. Moradi and P.A. Azar, J. Saudi Chem. Soc., 18, 348 (2014); https://doi.org/10.1016/j.jscs.2014.01.004.

49. S.M. Seyedi, B. Anvaripour, M. Motavassel and N. Jadid, Int. J. Eng. Innov. Technol., 2, 2277 (2013).

50. Y. Vijaya, S.R. Popuri, V.M. Boddu and A. Krishnaiah, Carbohydr. Polym., 72, 261 (2008); https://doi.org/10.1016/j.carbpol.2007.08.010.

51. W.S.W. Ngah, A. Kamari, S. Fatinathan and P.W. Ng, Adsorption, 12, 249 (2006); https://doi.org/10.1007/s10450-006-0501-0. 